\title{
India's Foreign Policy and Disarmament, CTBT and NPT
}

\author{
Dr. Hanumanthappa D G* \\ Assistant professor, Department of Post Graduate Studies and Research in Political Science, Rani Channamma \\ University, Vidy Sangama, Belagavi 591156, India
}

*Corresponding Author: Dr. Hanumanthappa D. G, Assistant professor, Department of Post Graduate Studies and Research in Political Science, Rani Channamma University, Vidy Sangama, Belagavi 591156, India

\begin{abstract}
Primarily India is a strong believer in panchasheela principles. The most pr-eminent principle is non-aggression, and India is one of the glaring examples which, after it's metamorphoisation into a nation state based on democratic principles after it's glories independence, perused non-aggression policy. It is this panchsheela principle helped India turn into an impeccable non-aligned countries leadership. The Indian state as non aliened and non-aggression country continued to exist unstained till 1962 when beguiled china waged a war against India and hence rethinking and restructuring India's foreign policy took. One must revere India's far-sightedness and sagacity, when there where efforts to convince India to sign NPT and CTBT international facts. India did not sign and by not signing such facts India prudently retained its right of free existence, otherwise it could have been constrained and constricted by itself, thank god, and no inadertelcnce could confound this country. India's not signing this fact was a judicious decision, but the relevance of global endorsement of CTBT and NPT has not yet lost the sight of. It is at this juncture and taking note of the belligerent attitudes of from within the nighourwood and across the global strategic actors, what could be the plausible stand India could undertake in the 21st century, is all what this paper throws it light on and also on the cadence of foreign policy in the perceptive of the 21 st century.
\end{abstract}

Keywords: Panchasheela principles, NPT and CTBT, India's foreign policy.

\section{INTRODUCTION}

The national interest is protected through both internal growth and external foreign policy. Absolute reliance on foreign policy alone will not buttress the fulfillment of national interest. The pulp of the foreign policy may be national interest, of course. It will be in terms of substantive existence. This paper argue that internal and inbuilt strength, capacity and capability in terms of innovations,, skills, and other the requisites put together that steer the national life and of the human resources, harmony and collective order for development that not only safeguards the national interest but also strengthens the foreign policy, and this process, in return, would enhance the bargaining power of a nation to its advantage. The nation's internal strength buttress role in the territorial integrity and sovereignty of India.

If we carefully look into the congress foreign policy dimensions like look east, west, ASEAN were just diffident policies, which, I can term them as 'safe foreign policy' which were not that successful, they met with lots of interactions and economically were not advantages to India. Rajiv Gandhi's meek foreign policy made little dent in ICT. But, however, Rajeev foreign policy was not based on India's internal strength, which means not based purely on barging strength.

On the contrary, the present incumbent Modi-Government proving its mettle in foreign policy and earning lots of dividends to India. Modi foreign policy is result oriented. His visits so far to many countries have produced profitable results, his bargaining posture in international arena, unlike his predecessors, displays national guts. He displays India's strength as an embodiment of national spirit and go straight for bargaining, hence, the results. Modi, as a capable PM of India, poignantly demonstrate India's underlying strength and blooming India's advancement across sundry fields and thus successfully entangles is counterparts, through his uncompromising foreign policy in the of international realm.

"Strong country, strong foreign policy, week country, week foreign policy" 
In the context of this statement, let us take USA foreign policy, Russian foreign policy, Israel foreign policy, and chine's foreign policy, all put together; reflect the respective in built strength that catapults the national leadership to assert their national interest in an aggressive manner. The socioEconomic prosperity of a nation people could well be accomplished through skills development programmes that subsequently leads to the creation of opportunities for diverse talent, since, the postmodern phase based on knowledge and information, can well act as a mainstay for wide -spread creation of skills at the domestic level strengthening the hands of national leadership to pocket profitable opportunities in the international market through the instrument of foreign policy.

Trade sector is an important activity that foreign policy can succeed in, provided the foreign policy of a nation takes into account the trade relations of stake holders. This sector plays a pivotal role for countries like India in $21^{\text {st }}$ century as the trade sector alone is likely to dominant it. If India wants to benefit from trade relations through foreign policy, it must ensure that the domestic industries respond to the requirements of international markets. This is a challenging job for India's foreign policy to locate market for its goods and this can happen only if India's foreign policy is for-sighted and ably responds to the futuristic needs of the international community.

\section{INDIA'S FOREIGN POLICY IN THE CONTEXT OF CTBT AND NPT}

India's foreign policy, since its origin, was opposed to nuclear programme. This was Nehru's view, and he envisaged disarmed globe. But India eventually assumed a divergent view in the face of china's war in 1962 and also china's nuclear test in 1964. This means, china's strategies derange prompted India to go nuclear. Prime Minister Lalbahddur Shastri gave a clarion call for peaceful nuclear explosion in 1964. In addition to this in parliament he declared that India shall never fabricate bomb. However, India conducted its first nuclear test in May 1974, with view to secure its security guarantee from mighty countries in nuclear power. With pokran-I, India consistently attempted to vindicate its goal of nuclear disarmament. Following Pokran-II, India in 1998 tested its own nuclear capability under Pokran-II programme and justified this attempt on the basis of national security being under threat. Even after these two events India remains consistent in its policy of nuclear disarmament and upheld it as its principle objective.

India tested nuclear weapon more than once in may 1974 and second in may 1998, but claims it is domestic in nature and that should not be construed as instrument of proliferation, India being one of the four nations, did not sign NPT and also CTBT, the reason simply, being the discriminatory attitudes of nuclearised nations, this was sheer policy of nuclear powerful nations to dictate their hegemonic terms and conditions to have note. Not only this, but also, the nuclear power holders constricting the have not's without taking into account, the security concerns of have not's, thus protecting their own strategic interests and stock files.

India desisted from signing CTBT (Comprehensive test Ban treaty) for it allowed sub-kiloton tests under stockpile stewardship. India initiative to reject CTBT display its indifference to the advanced research carried out by nuclear power states. India successfully discerned the underlying designs of CTBT and its being forced upon have not and their ulterior designs to disarm them. However, India upright believed that the aim of the CTBT should not only be to end nuclear testing but also, convincer the international community, cense the qualitative development and refinement of nuclear weapons by any means. The CTBT allows enough space for manufacturing leaner and meaner. War heads for cuts quantitatively in P-5 arsenal.

With this background, India opines that Non-Proliferation treaty bolsters P-5 to retain their power structures as earlier besides, driving all non (Nuclear Power State) with more strident measures against them. The NPT never shows any concern for P-5 being restrained nor does it ever make any attempt towards P-5 to make them go eventual disarmament. Though, India has never signed NPT but it certainly is glued to the contents of NPT that pertains to the P-5 (Nuclear Power State). Article one of the NPT Solemnly declares that no country shall convey nuclear weapons and assist any country in acquiring the knowhow of nuclear technology. India's Track Record in this context incontestable and irrefutable (India is stand impeccable). However, certain nuclear power states being strayed furtively collaboration with non-nuclear states sand transferring the required nuclear technology for illegal proliferation of nuclear weapons. Further Article VI of NPT obliges the states that are parties to the treaty to cut down nuclear stock files leading to global nuclear discernment. India, the lone country, in the world that persistently sticking and compiling with the contents of NPT and also the singular nuclear power ever ready to sacrifice for the cause of nuclear discernment. 


\section{CONCLUSION}

India's foreign policy as for as NPT and CTBT are concerned, is quite prudent and sagacious. India is undertaking an utterly pragmatic step with its watchful eyes (across developments of nuclear weapons at the international level). India's cautious move was displayed when it declined to sign NPT and its far sightedness regarding threats to its territorial integrity and sovereignty must be admired.

I bum, henceforth that India must be watchful and take guarded steps i.e., practical steps that would certainly go a long way in protecting the national sovereignty and should not compromise the strategic strength of India and it must be kept updated. This does not mean that India should develop nuclear weapons, surely not, but never forget to refine the minds on nuclear technology at the laboratories.

\section{REFERENCES}

[1] Abhinandan, Dr. Netajee; India‘s Push for Permanent Membership of Security Council: The China Factor; World Focus, Nov.-Dec. 2010, p.532.

[2] Dutt, V.P.; India‘s Foreign Policy: since Independence; National Book Trust, India, 2010, p.1.

[3] Chopra, V.D. (Ed.); India's foreign Policy in the 21 'st Century; Kalpaz publications, Delhi, 2006, p.7.

[4] Gharekhan, Chinmaya R.; On pursuing Independent Foreign Policy, The Hindu, Sept. 12, 2009.

[5] Kumar, Mahendra; Theoretical Aspect of International Politics, Shivalal Agrawal \& CO. Agra, (seventh ed.), p.302-03.

[6] Kumar, Madhurendra; Challenges before India's Foreign Policy in 21 'st Century; from Annpurna Nautiyal (Ed.); Challenges to India's Foreign Policy in New Era, Gyan Publishing House, New Delhi, 2006, p.71.

[7] Gahlaut, Seema; India and the Non-proliferation Regime, from Subrat K. Mitra \& Bernd Rill (Ed.); India‘s New Dynamics in Foreign policy, Hanns Seidel Foundation, 2006, pp. 93-106, http://www.hss.de.

[8] Shukla, Subhash; Foreign Policy of India; Anamika Publishers and Distributors (P) LTD, New Delhi, 2007, p.76.

[9] Singh, Dr. Bhupendra Kumar; Ensuring India‘s Energy Security, World Focus, Nov.-Dec. 2009, p. 521.

[10] Upreti, B.C.; India‘s Relations with the ASEAN Countries: Building a New Partnership; ibid. P.331.

Citation: Dr. Hanumanthappa D. G. "India's Foreign Policy and Disarmament, CTBT and NPT". International Journal of Political Science (IJPS), vol5, no.1, 2019, pp.4-6. doi:http://dx.doi.org/10.20431/2454-9452.05 01002.

Copyright: (C) 2019 Authors. This is an open-access article distributed under the terms of the Creative Commons Attribution License, which permits unrestricted use, distribution, and reproduction in any medium, provided the original author and source are credited. 